\title{
KOMPARASI BIAYA PENGGUNAAN KAYU DAN BAJA RINGAN UNTUK KONTRUKSI KUDA-KUDA
}

\author{
Hery Kristiyanto ${ }^{1}$, Agung Yuntoro ${ }^{2}$ \\ E-mail: heryjogja90@gmail.com
}

\begin{abstract}
ABSTRAK: Perencanaan gedung pada saat ini sangat dipengaruhi oleh banyak faktor namun semua ditujukan untuk mencapai suatu struktur yang kuat dan ekonomis. Termasuk dalam hal perencanaan struktur atap yang mempunyai beberapa macam variasi bahan material yang dapat digunakan untuk bahan rangka dan bahan pembuatan kuda-kuda.Tujuan penelitian ini adalah untuk mengetahui perbedaan biaya pada pekerjaan struktur rangka atap dengan kuda-kuda dari kayu dengan kuda-kuda dari baja ringan.

Pengumpulan data secara langsung dari lapangan dengan ditunjang data literatur untuk perencanaan. Struktur kuda-kuda yang terpasang dilapangan adalah baja ringan. Dalam perencanaan menggunakan peraturan pembebanan PPIUG tahun 1987 dan analisa pekerjaan menggunakan SK-SNI. Untuk perhitungan gaya batang dalam perencanaan kuda-kuda menggunakan metode join.

Anggaran biaya untuk pekerjaan atap dengan kuda-kuda dari kayu bengkirai mutu kayu A adalah Rp 113.803.728,77. Sedangkan anggaran biaya untuk pekerjaan kuda-kuda baja ringan yang terpasang Rp 114.285.600,00.Selisih biaya antara penggunaan kuda-kuda kayu dengan kudakuda baja ringan adalah Rp 481.871,23. Prosentase selisih biaya terhadap nilai pekerjaan adalah $0,42 \%$. Perbedaan ini menjadi lebih besar ketika penggunaan penutup atap diperhitungkan karena struktur baja ringan menuntut material penutup atap yang ringan dengan harga yang lebih mahal.Biaya setelah penutup atap diperitungkan untuk rangka atap dengan kuda-kuda baja ringan dengan penutup atap dari metal roof biaya mencapai $R p$ 186.373.440,00. Sedangkan rangka atap dengan kuda-kuda kayu untuk penggunaan genteng tanah liat mencapai biaya $R p$ 140.323.262,69 (prosentase selisih biaya $=24,7 \%$ ) dan untuk penggunaan genteng beton mencapai biaya $R p$ 146.431.388,45 (prosentase selisih biaya $=21,4 \%$ )
\end{abstract}

Kata kunci: kuda-kuda, biaya, bahan

\section{PENDAHULUAN}

\subsection{Latar Belakang Masalah}

Dalam pembangunan sebuah gedung diperlukan perencanaan yang baik apalagi gedung yang dipergunakan untuk fasilitas umum. Perencanaan yang dilaksanakan meliputi pekerjaan pondasi, pekerjaan beton/dinding, pekerjaan atap dan pekerjaanpekerjaan lainnya. Dari berbagai macam pekejaan itu dapat dilakukan dalam cara yang berbeda mengacu pada aspek-aspek tertentu yang harus dipertimbangkan sehingga pada akhirnya nanti dapat dicapai kualitas yang baik dengan biaya yang sesuai.

Pada pekerjaan rangka atap berdasarkan beban yang direncanakan berbagai macam pertimbangan dapat diambil sesuai bentuk dan material yang akan dipergunakan. Faktor harga, lokasi menjadi pertimbangan jika daerah disekitar mampu menyediakan kebutuhan material yang diperlukan. Keadaan dilokasi juga akan berpengaruh seperti keadaan angin, kelembaban, dan untuk daerah dekat pantai kandungan garam akan berpengaruh

1) adalah staf pengajar Program Studi Teknik Sipil Universitas Cokroaminoto Yogyakarta

2) adalah mahasiswa Program Studi Teknik Sipil Universitas Cokroaminoto Yogyakarta

11 Komparasi Biaya Penggunaan Kayu dan Baja Ringan Untuk Konstruksi Kuda-Kuda (Hery Kristiyanto, Agung Yuntoro) 
besar pada korositas bahan yang digunakan. Faktor lain yang menentukan adalah kemudahan dalam pelaksanaan konstruksi.

Masalah yang mungkin ditimbulkan berkaitan dengan besar kecilnya biaya sangat tergantung pada pemilihan jenis material yang akan digunakan. Pada saat ini telah banyak dikembangkan dan digunakan rangka atap dari baja ringan sebagai satu alternatif dari jenis rangka baja konvensional dan rangka atap kayu yang sudah lazim digunakan. Dengan membandingkan antara material yang satu dengan yang lain dapat diketahui dan dipilih jenis material yang paling ekonomis tapi dalam kekuatan konstruksi masih dapat dipertanggungjawabkan.

Untuk memberikan gambaran yang jelas tentang perbedaan antara penggunaan satu jenis material dengan material yang lain, maka penulis membuat batasan-batasan sebagai berikut (1) Analisa dalam penelitian ini hanya membahas struktur atap, (2) Material yang digunakan dalam objek penelitian ini adalah bahan dari jenis kayu bengkirai, (3) Untuk rangka atap baja ringan yang digunakan pada proyek pembangunan gedung SD Muh. Kalinampu I Pundong, Bantul, Yogyakarta, tidak dihitung ulang tapi diambil harga total dari pekerjaan tersebut untuk dibandingkan dengan harga total dari perhitungan dalam penelitian ini.

\subsection{Tujuan Penelitian}

Tujuan dari penulisan Penelitian ini adalah mengetahui perhitungan beban pekerjaan rangka atap kayu, biaya pekerjaan rangka atap kayu, dan menganalisa perbedaan biaya antara penggunaan kuda-kuda dari kayu dengan penggunaan kuda-kuda dari baja ringan.

\section{TINJAUAN PUSTAKA}

Menurut Salmon dkk (1994) perencanaan struktur dapat didefinisikan sebagai paduan antara seni dan ilmu yang menggabungkan intuitif seorang insinyur berpengalaman dalam kekakuan sruktur dengan pengetahuan mendalam tentang prinsip struktur dinamika, mekanika bahan dan analisa struktur, untuk mendapatkan struktur yang ekonomis dan aman serta sesuai dengan tujuan pembuatannya.

Atap adalah bagian bangunan yang merupakan "mahkota", mempunyai fungsi untuk menambah keindahan dan sebagai pelindung bangunan dari panas dan hujan (Puspandoyo, 1984). Beberapa syarat yang harus dipenuhi untuk pekerjaan atap adalah : harus serasi dengan bangunannya sehingga dapat menambah keindahan dari bangunan, dibuat dengan kemiringan sedemikian, sehingga air hujan dapat cepat meninggalkan atap bangunan, harus dibuat dari bahan yang tahan dan tidak mudah rusak oleh pengaruh cuaca, panas dan hujan, dan dapat memberikan kenyamanan bertempat tinggal bagi penghuninya. Pada rangka batang dua dimensi yaitu suatu sistem rangka yang strukturnya terbentuk dari elemen-elemen batang lurus yang dirangkai dalam bidang datar, dengan sambungan antar ujung-ujung batang diasumsikan "sendi sempurna". Beban luar yang bekerja di titik-titik buhul dengan arah sembarang dan sebidang dengan struktur tersebut. Pada sistem ini apabila semua persyaratan diatas dipenuhi maka semua elemen-elemen pembentuk sistem tersebut hanya akan mengalami gaya aksial desak atau tarik.

Menurut Soegeng Djojowirono (1984) yang dimaksud Rencana Anggaran Biaya /RAB (Begrooting) suatu bangunan atau proyek adalah perhitungan banyaknya biaya yang diperlukan untuk bahan dan upah serta biaya-biaya lain yang berhubungan dengan pelaksanaan bangunan atau proyek tersebut. Anggaran biaya merupakan harga dari bangunan yang dihitung dengan teliti, cermat dam memenuhi syarat. Anggaran biaya pada bangunan yang sama akan berbeda-beda dimasing-masing daerah, disebabkan karena perbedaan harga bahan dan upah tenaga kerja. 
Rencana anggaran biaya dibuat sebelum proyek dilaksanakan, jadi masih merupakan anggaran perkiraan bukan anggaran yang sebenarnya berdasarkan pelaksanaan (actual cost). Rencana anggaran biaya dihitung berdasarkan gambar-gambar rencana dan spesifikasi yang sudah ditentukan. Menurut John W Niron dalam buku "Pedoman Praktis Anggaran dan Borongan (Rencana Anggaran Biaya Bangunan)" 1990, Rencanan Anggaran Biaya adalah merencanakan suatu bangunan dalam bentuk dan manfaat penggunaannya serta besarnya biaya yang digunakan dan susunan-susunan dalam bidang administrasi maupun pelaksanan dibidang teknik. Jadi maksud dari pembuatan Rencana Anggaran Biaya adalah mengetahui biaya yang diperlukan pada suatu poyek pembangunan untuk memperoleh hasil yang diinginkan.

\section{METODOLOGI PENELITIAN}

Data untuk keperluan pembuatan penelitian ini terdiri dari data-data berikut :

1. Data primer adalah data-data yang diperoleh langsung dari lapangan.

2. Data sekunder adalah data yang diambil dari Konsultan Perencana (CV. Tri Matra) dan dari Konsultan Pelaksana (CV. Nusantara) maupun dari Konsultan Pengawas (CV. Cipta Sarana)

\section{Landasan Teori}

\subsection{Pembebanan dan Tegangan}

Beban Mati (M) adalah berat semua bagian dari suatu gedung yang bersifat permanen yang merupakan bagian yang terdapat dalam gedung. Dalam perencanaan digunakan acuan PPIUG tahun 1983. Untuk Beban Hidup $(\mathrm{H})$ pada atap gedung, yang dapat dicapai dan dibeban oleh orang, harus diambil $100 \mathrm{~kg} / \mathrm{m}^{2}$ bidang datar. Menurut PPIUG tahun 1983 Beban Angin ditentukan dengan anggapan adanya tekanan positif (tekan) dan tekanan negatif (isap) yang bekerja tegak lurus bidang yang ditinjau, besarnya tekanan ini diperoleh dengan mengalikan koefisien angin dengan tekanan tiup dari angin. Tekanan tiup minimum $25 \mathrm{~kg} / \mathrm{m}^{2}$. Untuk gedung tertutup (ada dinding) dengan sudut kemiringan atap $\alpha \leq 65^{\circ}$ dan $65^{\circ} \leq \alpha \leq 90^{\circ}$ termasuk atap parabola, koefisien angin sebesar $-0,4$. Untuk gedung yang terbuka sebelah (dinding ada pada satu sisi) dengan sudut atap $\alpha \leq 65^{\circ}$ dan $65^{\circ} \leq \alpha \leq 90^{\circ}$, pada pihak angin koefisiennya -1 , serta pada belakang angin koefisien angin $-0,1$. Untuk perencanaan suatu konstruksi, perlu diketahui tegangan ijin dari kayu yang akan digunakan dalam perencanaan itu. Untuk setiap macam kayu kita bagi menjadi 2 mutu. Yaitu mutu kayu A dan mutu kayu B.

Table 1 Tegangan yang dipergunakan untuk kayu mutu $\mathrm{A}\left(\mathrm{kg} / \mathrm{cm}^{2}\right)$ :

\begin{tabular}{|c|c|c|c|c|c|c|}
\hline \multirow{2}{*}{ TEGANGAN } & \multicolumn{5}{|c|}{ KLAS KUAT } & \multirow{2}{*}{ JATI } \\
\cline { 2 - 6 } & $\mathrm{I}$ & $\mathrm{II}$ & $\mathrm{III}$ & $\mathrm{IV}$ & $\mathrm{V}$ & 130 \\
\hline $\bar{\sigma} \mathrm{It}$ & 150 & 100 & 75 & 50 & - & 110 \\
\hline $\bar{\sigma} \mathrm{ds} / /=\bar{\sigma} \mathrm{tr} / /$ & 130 & 85 & 60 & 45 & - & 30 \\
\hline $\bar{\sigma} \mathrm{ds} \perp$ & 40 & 25 & 15 & 10 & - & 15 \\
\hline $\bar{\tau} / /$ & 20 & 12 & 8 & 5 & - & \multirow{2}{*}{} \\
\hline
\end{tabular}

Dengan adanya pengaruh keadaan konstruksi dan muatan, maka angka-angka tersebut harus dikalikan dengan :

1. Faktor $2 / 3$ : untuk konstruksi yang selalu terendam air dan untuk konstruksi yang tidak terlindung dan kemungkinan kadar lengas kayu akan tinggi, misalnya didalam terowongan dan sebagainya.

2. Faktor $5 / 6$ : untuk konstruksi yang tidak terlindung. Tetapi kayu itu dapat mengering dengan cepat, misalnya pada jembatan, perancah dan sebagainya.

13 Komparasi Biaya Penggunaan Kayu dan Baja Ringan Untuk Konstruksi Kuda-Kuda (Hery Kristiyanto, Agung Yuntoro) 
3. Faktor $5 / 4$ : untuk bagian konstruksi yang tegangannya diakibatkan oleh muatan tetap dan muatan angin dan untuk bagian-bagian konstruksi yang tegangannya diakibatkan oleh muatan tetap dan muatan tidak tetap.

Untuk bagian-bagian yang arah gayanya membentuk sudut $\alpha$ dengan arah serat kayu, maka tegangan harus dihitung sebagai berikut :

$$
\bar{\sigma} \mathrm{tk} \alpha=\bar{\sigma} \mathrm{tk} / /-\left(\bar{\sigma}_{\mathrm{tk} / /}-\bar{\sigma}_{t k \perp}\right) \sin \alpha .
$$

Jika balok dibebani momen maka serat-serat tepi atas terdesak dan tepi bawah tertarik. Dari rumus

$$
\sigma . l t=\frac{M}{W n}
$$

untuk menentukan ukuran dipakai rumus

$$
\mathrm{W}=\frac{1}{6} \mathrm{bh}^{2}=\frac{M}{\sigma \cdot l t}
$$

Pada balok lentur ukuran harus cukup besar sehingga tegangan tidak melebihi yang diijinkan, juga lendutan ditengah balok tidak boleh melebihi batas. Dengan mengabaikan pergeseran pada tempat-tempat sambungan, lendutan pada suatu konstruksi akibat berat sendiri dan muatan tetap dibatasi untuk balok yang digunakan pada konstruksi terlindung lendutan maksimal $f_{\text {mak }} \leq \frac{1}{300} \mathrm{~L}$, balok pada konstruksi tidak terlindung $\mathrm{f}_{\text {mak }} \leq \frac{1}{400} \mathrm{~L}$; dan pada konstruksi kuda-kuda, gording, kasau dan sebagainya : $f_{\text {mak }} \leq \frac{1}{200} L$ dimana $f$ adalahlendutan, $\mathrm{L}$ adalah jarak.

Apabila suatu konstruksi, karena suatu sebab menderita tegangan lentur dan tegangan tarik bersama, maka harus dihitung :

$$
\begin{aligned}
& \sigma=\frac{S}{F n}+\varphi_{1} \frac{M}{W n} \leq \sigma \operatorname{tr} / / \\
& \varphi_{1}=\frac{\sigma \cdot t r / /}{\sigma . l t}
\end{aligned}
$$

Dimana $\sigma$ adalah tegangan, $\mathrm{S}$ adalah gaya tekuk, $\mathrm{Fn}$ adalah Luas penampang netto, $\mathrm{M}$ adalah momen, dan $\mathrm{Wn}$ adalah momen penahan netto.

Apabila suatu bagian konstruksi menderita tegangan lentur dan tegangan tekan bersama, maka harus dihitung :

$$
\begin{aligned}
& \sigma=\frac{S \cdot \omega}{F \cdot b r}+\varphi_{2} \frac{M}{W n} \leq \sigma \mathrm{tk} / / \\
& \varphi_{2}=\frac{\sigma \cdot t k / /}{\sigma \cdot l t}
\end{aligned}
$$

Dimana S adalah gaya tekan dan Fbr adalah Luas penampang bruto

Untuk balok dengan $\mathrm{h}<\frac{1}{12} \ell$ maka $\mathrm{f}_{\text {mak }}=\frac{5}{384} \times \frac{Q \cdot \ell^{3}}{E . I}$ 
Untuk keperluan menghitung lenturan suatu balok dan batang tertekuk diperlukan Modulus kenyal (E) kayu sejajar arah serat. Kuat kayu kelas I mempunyai $E=125.000$ $\left(\mathrm{kg} / \mathrm{cm}^{2}\right)$, Jati kelas II mempunyai $E=100.000\left(\mathrm{~kg} / \mathrm{cm}^{2}\right)$, kelas III mempunyai $E=80.000$ $\left(\mathrm{kg} / \mathrm{cm}^{2}\right)$, dan Jati kelas IV mempunyai $\mathrm{E}=60.000\left(\mathrm{~kg} / \mathrm{cm}^{2}\right)$,

Batang tekan (compression member) adalah elemen struktur yang mendukung gaya tekan aksial. Pada batang-batang yang menderita tegangan desak, tegangan yang terjadi harus dimodifikasi dengan suatu faktor tekuk yang besarnya tergantung pada jarijari inersia, panjang tekuk batang dan jenis batang.panjang tekuk batang diperoleh dengan mengalikan faktor panjang tekuk dengan panjang batang sebenarnya. Berdasarkan PPIUG tahun 1983 nilai faktor panjang tekuk ditentukan berdasarkan kombinasi dari perletakannya.

Untuk batang yang menahan tegangan tekan, panjang tekuk $\left(\ell_{k}\right)$ harus diambil sebesar jarak antara dua titik yang berturutan yang bebas tekukan. Bagian konstruksi yang akan menghindarkan tekukan harus diperhitungkan terhadap gaya dalam arah tekukan tersebut sebesar $1 \%$ dari gaya tekan terbesar yang bekerja disampingsampingnya.

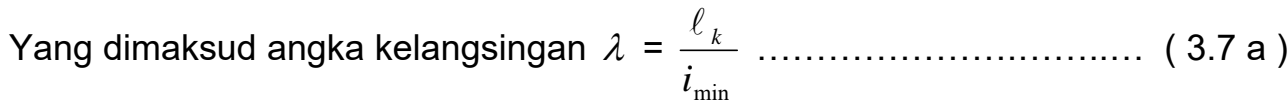

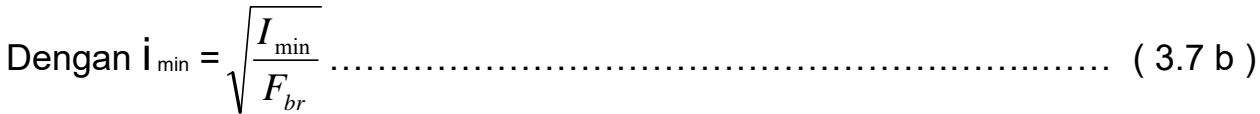

Dimana $\ell_{k}=$ panjang tekuk, $\mathrm{i}_{\min }=$ jari-jari inersia, $\mathrm{I}_{\min }=$ momen inersia, $\mathrm{F}_{\mathrm{br}}=$ luas tampang batang bruto. Tiap-tiap batang tertekan harus mempunyai $\lambda \leq 150$

Untuk menghindari tekuk pada batang tertekan, gaya yang ditahan oleh batang itu harus dikalikan dengan faktor tekuk $\omega$, sehinga :

$\sigma=\frac{S . \omega}{F_{b r}} \leq \sigma \mathrm{ds} / /$

Dimana $\sigma$ adalah Tegangan yang timbul, $\mathbf{S}$ adalah Gaya yang timbul pada batang $\omega$ faktor tekuk.

\subsection{Batang Tarik}

Batang tarik adalah batang yang mendukung tegangan tarik aksial yang diakibatkan oleh bekerjanya gaya tarik aksial pada ujung-ujung batang. Pada batang tarik bagian-bagian yang dibebani dengan tegangan lentur, perlemahan akibat lubang untuk alat sambung harus diperhitungkan. Tegangan tarik batas dapat dicapai dengan mudah bila sambungan ujung direncanakan lebih kuat daripada kekuatan batangnya. Dalam perencanaan batang tarik luas tampang batang diambil perlemahan $20 \%$ sampai $25 \%$ untuk sambungan dengan baut.

Perencanaan batang tarik harus ditinjau dari beberapa segi yakni tegangan, pelayanan, keliatan, dan ketahanan. Tegangan (stress), ukuran harus dipilih sedemikian rupa sehingga tegangan yang terjadi kurang atau sama dengan tegangan tarik ijin. Dari perbandingan tarik ijin dapat diketahui hemat tidaknya perencanaan. Semakin dekat tegangan yang terjadi dari tegangan ijinnya maka perencanaan dikatakan ekonomis. Pelayanan (servicebility). Struktur tidak diperkenankan menunjukan perilaku yang

15 Komparasi Biaya Penggunaan Kayu dan Baja Ringan Untuk Konstruksi Kuda-Kuda (Hery Kristiyanto, Agung Yuntoro) 
mengkhawatirkan pemakai. Misalnya defleksi yang berlebihan, bergetarnya elemen struktur oleh kendaraan yang bergerak dan sebagainya. Dalam hal ini kelangsingannya harus dibatasi. Sifat Keliatan (ductility) merupakan persyaratan yang paling penting. Tanpa daktilitas yang baik tidak akan terjadi redistribusi tegangan yang menyebabkan hitungan menjadi sederhana khususnya pada perencanaan plastis. Sifat ini diketahui dari percobaan tarik. Ketahanan (durability) terhadap cuaca panas dan dingin, korosi atau suhu yang menigkat perlu diperhatikan. Konstruksi terlindung atau konstruksi di luar juga berpengaruh dalam ketahanan, dalam perencanaan atap konstruksi rangka terlindung oleh penutup atap.

\subsection{Sambungan}

Di dalam konstruksi kayu yang meminta perhatian besar adalah tempat-tempat hubungan atau sambungan, karena sambungan selalu merupakan merupakan titik terlemah pada suatu konstruksi. Dalam hal ini jenis sambungan yang dipakai adalah

\section{Sambungan gigi}

Pada sambungan gigi gesekan antara kayu dengan kayu didalam perhitungan diabaikan. Untuk sambungan gigi tunggal dalamnya gigi tidak boleh melebihi batas tertentu yaitu : tv $\leq 1 / 4 \mathrm{~h}$ untuk $\alpha \leq 50^{\circ}$, tv $\leq 1 / 6 \mathrm{~h}$, untuk $\alpha>60^{\circ}$

untuk $50^{\circ}<\alpha \leq 60^{\circ}$ nilai $\mathrm{h}$ dicari dengan interpolasi.

Digunakan rumus : $\mathrm{tv}=\frac{S}{112 b}$

Perhitungan kayu muka

$$
\begin{aligned}
& \mathrm{Lv}=\frac{S \cdot \cos \alpha}{b \cdot \tau_{I I}} \leq 30 \mathrm{~cm} \\
& \mathrm{ts}=\frac{t v}{\cos 1 / 2 \alpha} \ldots \ldots \ldots \ldots . . \\
& \sigma \frac{1}{2} \boldsymbol{\alpha}=\frac{S \cdot \cos 1 / 2 \alpha}{b . t s} .
\end{aligned}
$$

Dengan $\sigma \boldsymbol{\alpha}=\sigma \mathrm{ds} / /-(\sigma \mathrm{ds} / /-\sigma \mathrm{ds} \perp) \sin \alpha$

$$
\sigma \frac{1}{2} \alpha=\sigma \mathrm{ds} / /-(\sigma \mathrm{ds} / /-\sigma \mathrm{ds} \perp) \sin \frac{1}{2} \alpha
$$

\section{Sambungan baut}

Baut sebagai alat penyambung banyak dipakai karena kemudahan dalam pemasangan dan pengadaan, meskipun sebenarnya tidak begitu baik karena efisiensi rendah dan deformasi besar. Sambungan dengan baut dibagi dalam 3 golongan menurut kekuatan kayu. Dengan kayu bengkirai termasuk (kelas kuat I), golongan I, digunakan rumus untuk sambungan golongan I tampang 1

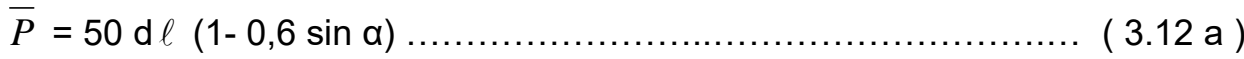

$$
\begin{aligned}
& \bar{P}=240 \mathrm{~d}^{2}(1-0,35 \sin \alpha)
\end{aligned}
$$

Untuk sambungan dengan baut mempunyai syarat-syarat sebagai berikut : 
a) Alat sambung baut harus terbuat dari baja $s_{t} 37$ atau dari besi yang mempunyai kekuatan paling sedikit seperti $\mathrm{s}_{\mathrm{t}} 37$.

b) Lubang baut harus dibuat secukupnya saja dan kelonggaran harus $\leq 1,5 \mathrm{~mm}$.

c) Garis tengah baut harus $\geq 10 \mathrm{~mm}$ ( $\frac{3}{8}$ "), sedang untuk sambungan baik tampang satu maupun tampang dua, dengan tebal kayu lebih besar dari $8 \mathrm{~cm}$, harus dipakai baut dengan garis tengah $\geq \frac{1}{2} "$.

d) Baut harus disertai cincin-tutup yang tebalnya $\leq 0,3 \mathrm{~d}$ dan $\leq 5 \mathrm{~mm}$ dengan garis tengah $3 d$, atau jika mempunyai bentuk persegi empat lebarnya $\geq 3 d$, dimana $d=$ garis tengah baut.jika bautnya hanya sebagai perekat maka tebal cincin-tutup dapat diambil 0,2 d dan maksimum $4 \mathrm{~mm}$.

e) Apabila pada sambungan digunakan plat dari besi (baja), atau pada sambungan tampang dua plat-plat sambungnya terbuat dari besi (baja), maka nilai $\mathrm{P}$ dinaikan dengan $25 \%$.

f) Apabila baut tersebut digunakan pada konstruksi yang tidak terlindung maka didalam perhitungan kekuatannya harus dikalikan dengan angka $\frac{5}{6}$ dan apabila dipergunakan pada konstruksi yang selalu basah maka kekuatannya harus dikalikan $\frac{2}{3}$.

g) Jika gaya yang didukungnya itu disebabkan oleh beban sementara, maka kekuatan sambungan dapat dinaikan dengan $25 \%$.

\subsection{Kuda-kuda}

Kuda-kuda adalah bagian yang memberikan bentuk kepada atapnya dan sekaligus berfungsi sebagai pendukung atapnya. Kuda-kuda dibuat dengan cara merangkaikan beberapa batang kayu yang dibentuk menjadi suatu konstruksi rangka batang dengan bentuk dasar segitiga. Untuk menentukan ukuran kayu yang akan dipakai dapat dihitung dengan metode Cremona terhadap beban atap yang didukungnya, dengan anggapan kuda-kuda terletak pada tumpuan sendi dan rol.

\subsection{Rencana Anggaran Biaya}

Estimasi biaya/rencana anggaran biaya merupakan perkiraan perhitungan biayabiaya yang diperlukan untuk tiap pekerjaan dalam proyek konstruksi sehingga diperoleh biaya total yang diperlukan untuk menyelesaikan proyek tersebut.

1. Volume / Kubikasi Pekerjaan. Volume suatu pekerjaan adalah menghitung jumlah banyaknya volume pekerjaan dalam satu satuan. Volume juga disebut kubikasi pekerjaan. Jadi volume (kubikasi) suatu pekerjaan, bukanlah volume (isi sesungguhnya) melainkan jumlah volume bagian pekerjaan dalam satu kesatuan. Volume pekerjaan mempunyai uraian terperinci. Yang dimaksud uraian volume pekerjaan adalah menguraikan secara rinci besar volume atau kubikasi suatu pekerjaan. Menguraikan berarti menghitung besar volume masing-masing pekerjaan sesuai dengan gambar bestek dan gambar detail.

2. Harga Satuan Pekerjaan. Harga satuan pekerjaan ialah jumlah harga bahan dan upah tenaga kerja berdasarkan perhitungan analisis. Harga bahan didapat dipasaran dikumpulkan dalam satu daftar yang dinamakan Daftar Harga Satuan Bahan. Upah tenaga kerja didapatkan dilokasi dikumpulkan dan dicatat dalam satu daftar yang dinamakan Daftar Harga Satuan Upah. 


\section{PEMBAHASAN}

\subsection{Data Dan Perencanaan}

Data teknis untuik perencanaan panjang kuda-kuda $7 \mathrm{~m}$, tinggi kuda-kuda 2,2 m.

Tabel 2 Ukuran Bangunan

\begin{tabular}{|c|c|c|c|c|}
\hline gedung & panjang & lebar & Jumlah kuda-kuda & Jarak antar kuda-kuda \\
\hline A & 20 & 7 & 5 & 3,33 \\
\hline B & 26 & 7 & 7 & 3,25 \\
\hline C & 24 & 7 & 7 & 3,00 \\
\hline
\end{tabular}

Jarak antar gording $(L)=2,067 \mathrm{~m}$, kemiringan atap $\alpha=32^{\circ}$, jarak antar kuda-kuda $(X)=$ $3,33 \mathrm{~m}$ diambil yang terpanjang yaitu pada gedung $\mathrm{A}$

Tabel 3 Panjang Batang

\begin{tabular}{|c|c|c|c|}
\hline No batang & Jenis batang & Panjang batang $(\mathrm{m})$ & Panjang total $(\mathrm{m})$ \\
\hline $\mathrm{a}_{1}=\mathrm{a}_{2}=\mathrm{a}_{3}=\mathrm{a}_{4}$ & atas & 2,0670 & 8,268 \\
$\mathrm{~b}_{1}=\mathrm{b}_{2}$ & horisontal bawah & 3,5 & 7 \\
$\mathrm{~b}_{3}$ & horisontal atas & 3,5 & 3,5 \\
$\mathrm{~d}_{1}=\mathrm{d}_{2}$ & diagonal & 2,0670 & 4,134 \\
$\mathrm{v}_{1}$ & vertikal & 2,2 & 2,2 \\
\hline \multicolumn{2}{|c|}{,Panjang total } & 25,102 \\
\hline
\end{tabular}

\subsection{Perhitungan Beban Tetap}

- Beban mati $P=2,0670 \cdot 3,3.50=339,9 \mathrm{~kg}$

- Beban kuda-kuda $P=63,96 \mathrm{~kg}$

- Beban penggantung dan langit-langit $P_{5} a=83,16 \mathrm{~kg}$

- Beban gording $P=57,66 \mathrm{~kg}$

- Beban hidup $P=613,899 \mathrm{~kg}$

Total Beban Tetap $\mathrm{P}_{1}=339,9+63,96+83,16+57,66+613,899=1158,579 \mathrm{~kg}$

\subsection{Analisa Gaya Batang Akibat Beban Tetap}

Dengan metode join untuk mencari gaya batang kuda-kuda

Tabel 4 Gaya Batang

\begin{tabular}{|c|c|c|}
\hline Batang & Tarik (+) kg & Desak (-) kg \\
\hline$a_{1}=a_{4}$ & - & 3258 \\
$a_{2}=a_{3}$ & - & 2172 \\
$b_{1}=b_{2}$ & 2763 & - \\
$d_{1}=d_{2}$ & - & 1086 \\
$v_{1}$ & 1153 & - \\
\hline
\end{tabular}




\subsection{Analisa Gaya Batang Akibat Beban Angin}

Menurut PPIUG 1983, Tekanan tiup harus diambil minimum $25 \mathrm{~kg} / \mathrm{m}^{2}$. koefisien angin untuk bangunan tertutup, atap segitiga dengan kemiringan $\alpha<65^{\circ}$ dipihak angin adalah $0,02 \alpha-0,4$ dibelakang angin untuk semua $\alpha$ adalah $-0,4 \alpha$. Gaya angin tekanan adalah $(0,02.32-0,4) .25=6 \mathrm{~kg} / \mathrm{m}^{2}$, Gaya angin tiup $=-0,4.25=-10 \mathrm{~kg} / \mathrm{m}^{2}$

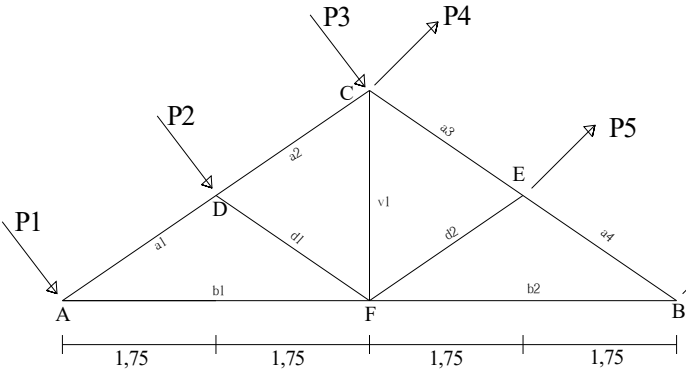

Gambar 1 Gaya Akibat Angin

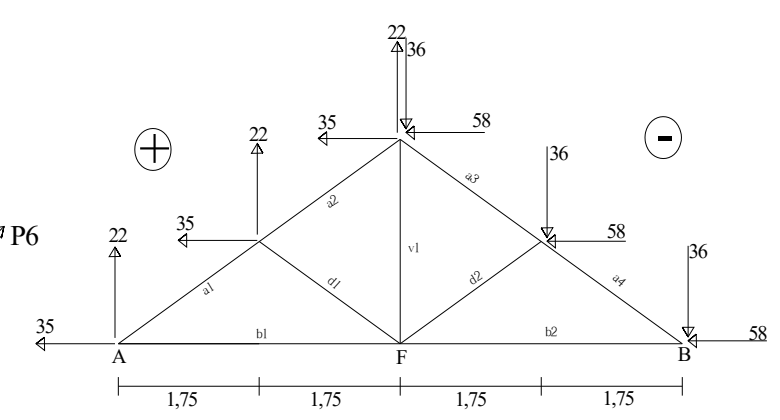

Gambar 2 Gaya Akibat Angin Kiri

Tabel 5 Gaya Akibat Angin Kiri

\begin{tabular}{|c|c|c|}
\hline Batang & Gaya batang tekan $(-)$ & Gaya batang tarik $(+)$ \\
\hline $\mathrm{a}_{1}$ & 81 & - \\
$\mathrm{a}_{2}$ & 43 & - \\
$\mathrm{a}_{3}$ & - & 28 \\
$\mathrm{a}_{4}$ & - & 28 \\
$\mathrm{~b}_{1}$ & - & 34 \\
$\mathrm{~b}_{2}$ & 81 & - \\
$\mathrm{d}_{1}$ & - & 41 \\
$\mathrm{~d}_{2}$ & 43 & - \\
$\mathrm{v}_{1}$ & - & 45 \\
\hline
\end{tabular}

Tabel 6 Kombinasi Gaya Batang

\begin{tabular}{|c|l|l|l|l|l|l|}
\hline Batang & $\begin{array}{l}\text { Gaya Beban } \\
\text { Tetap }\end{array}$ & $\begin{array}{l}\text { Gaya } \\
\text { Beban } \\
\text { Angin Kiri }\end{array}$ & $\begin{array}{l}\text { Gaya Beban } \\
\text { Angin Kanan }\end{array}$ & $\begin{array}{l}\text { Beban } \\
\text { Sementara }\end{array}$ & $\begin{array}{l}\text { Beban } \\
\text { Sementara }\end{array}$ & $\begin{array}{l}\text { Beban } \\
\text { Rencana }\end{array}$ \\
\hline $\mathrm{a}_{1}$ & -3258 & -81 & +81 & -3339 & -3177 & -3339 \\
$\mathrm{a}_{2}$ & -2172 & -43 & +43 & -2215 & -2129 & -2215 \\
$\mathrm{a}_{3}$ & -2172 & +28 & -28 & -2144 & -2200 & -2200 \\
$\mathrm{a}_{4}$ & -3258 & +28 & -28 & -3230 & -3286 & -3286 \\
\hline $\mathrm{b}_{1}$ & +2763 & +34 & -34 & +2797 & +2729 & +2797 \\
$\mathrm{~b}_{2}$ & +2763 & -81 & +81 & +2682 & +2844 & +2844 \\
\hline $\mathrm{d}_{1}$ & -1086 & +41 & -41 & -1045 & -1127 & -1127 \\
$\mathrm{~d}_{2}$ & -1086 & -43 & +43 & -1129 & -1043 & -1129 \\
\hline $\mathrm{v}_{1}$ & +1153 & +45 & -45 & +1198 & +1108 & +1198 \\
\hline
\end{tabular}

\subsection{Menghitung Dimensi Batang Kuda-kuda}

Kayu yang dipakai untuk kuda-kuda adalah bengkirai merupakan kayu dengan kelas kuat I, dengan mutu kayu $\mathrm{A}$, konstruksi terlindung $(\beta=1)$ dan beban tetap $(\gamma=1)$

$$
\begin{aligned}
& \sigma \mathrm{lt}=150 \times 1 \times 1 \times 1=150 \mathrm{~kg} / \mathrm{cm}^{2} \\
& \sigma \mathrm{ds} / /=130 \times 1 \times 1 \times 1=130 \mathrm{~kg} / \mathrm{cm}^{2}
\end{aligned}
$$

19 Komparasi Biaya Penggunaan Kayu dan Baja Ringan Untuk Konstruksi Kuda-Kuda (Hery Kristiyanto, Agung Yuntoro) 


$$
\begin{aligned}
& \sigma \mathrm{ds} \perp=40 \times 1 \times 1 \times 1=40 \mathrm{~kg} / \mathrm{cm}^{2} \\
& \bar{\tau} / /=20 \times 1 \times 1 \times 1=20 \mathrm{~kg} / \mathrm{cm}^{2}
\end{aligned}
$$

Tabel 7 Ukuran Dimensi Batang

\begin{tabular}{|c|c|c|}
\hline batang & Panjang batang $(\mathrm{m})$ & Dimensi batang $(\mathrm{cm})$ \\
\hline $\mathrm{a}_{1}=\mathrm{a}_{2}=\mathrm{a}_{3}=\mathrm{a}_{4}$ & 2,0670 & $10 / 14$ \\
$\mathrm{~b}_{1}=\mathrm{b}_{2}$ & 3,5 & $10 / 14$ \\
$\mathrm{~d}_{1}=\mathrm{d}_{2}$ & 2,0670 & $8 / 12$ \\
$\mathrm{v}_{1}$ & 2,2 & $10 / 14$ \\
balok ikatan angin & 3,96 & $6 / 8$ \\
balok pengaku & 0,8 & $10 / 14$ \\
\hline
\end{tabular}

*) Kalkulasi sambungan

Kayu bengkirai merupakan kayu dengan kelas kuat $\mathrm{I}$, dengan mutu kayu $\mathrm{A}$, konstruksi terlindung $(\beta=1)$ dan beban tetap $(\gamma=1)$

\subsection{Harga Satuan Bahan}

Bahan-bahan yang akan dipergunakan dibuat dalam daftar harga satuan bahan dan untuk upah kerja dibuat dalam daftar satuan upah kerja. Berdasarkan peraturan Gubernur Daerah Istimewa Yogyakarta No : 17 tahun 2007 tentang standarisasi harga barang dan jasa (SHBJ) adalah :

Tabel 8 Daftar Harga Satuan Bahan dan Upah Kerja

\begin{tabular}{|l|l|c|r|l|l|r|r|}
\hline No & Jenis Bahan Bangunan & Satuan & Harga (Rp) & No & Jenis Upah & Satuan & Upah (Rp) \\
\hline 1 & Kayu bengkirai balok & $\mathrm{m}^{3}$ & 5.800 .000 & 1 & Tenaga/pekerja & Hari & 30.000 \\
2 & Kayu bengkirai reng & $\mathrm{m}$ & 3.480 & 2 & Tukang kayu & Hari & 37.500 \\
3 & Baut & $\mathrm{kg}$ & 10.900 & 3 & Kepala tukang & Hari & 37.500 \\
4 & Paku besar, sedang & $\mathrm{kg}$ & 9.250 & 4 & Mandor & Hari & 36.000 \\
5 & Paku reng & $\mathrm{kg}$ & 8.250 & & & & \\
6 & Paku usuk & $\mathrm{kg}$ & 8.250 & & & & \\
7 & Genteng tanah liat kodok & $\mathrm{bh}$ & 825 & & & \\
8 & Genteng beton & $\mathrm{bh}$ & 2.750 & & & \\
9 & Besi Strip Tebal 5mm & $\mathrm{kg}$ & 8.800 & & & & \\
\hline
\end{tabular}

\subsection{Harga Pekerjaan Dan Analisa}

Selanjutnya membuat daftar harga satuan pekerjaan dari daftar analisa pekerjaan berdasarkan SNI 3434 tahun 2007 dan daftar harga satuan bahan dan satuan upah kerja yang ada yaitu

\begin{tabular}{|c|c|c|c|c|c|}
\hline & Kebutuhan & Satuan & Indeks & Harga sat. (Rp) & $\begin{array}{l}\text { Jumlah } \\
\text { (Rp) }\end{array}$ \\
\hline \multirow[t]{3}{*}{ Bahan } & Balok Kayu & $\mathrm{m}^{3}$ & 1,100 & 5.800 .000 & 6.380 .000 \\
\hline & Besi Strip Tebal 5mm & $\mathrm{kg}$ & 15,000 & 8.800 & 132.000 \\
\hline & Paku $12 \mathrm{~cm}$ & $\mathrm{~kg}$ & 5,600 & 9.250 & 51.800 \\
\hline \multirow[t]{4}{*}{ Tenaga Kerja } & Pekerja & $\mathrm{OH}$ & 4,000 & 30.000 & 120.000 \\
\hline & Tukang Kayu & $\mathrm{OH}$ & 12,000 & 37.500 & 450.000 \\
\hline & Kepala Tukang & $\mathrm{OH}$ & 1,200 & 37.500 & 45.000 \\
\hline & Mandor & $\mathrm{OH}$ & 0,200 & 36.000 & 7.200 \\
\hline \multicolumn{5}{|c|}{ Jumlah harga per satuan pekerjaan } & 7.186 .000 \\
\hline
\end{tabular}

Tabel 9 Memasang $1 \mathrm{~m}^{3}$ kuda-kuda konvensional untuk kayu kelas kuat I 
Tabel 10 Memasang $1 \mathrm{~m} 3$ konstruksi gording

\begin{tabular}{|l|l|c|c|r|r|}
\hline \multicolumn{2}{|l|}{ Kebutuhan } & Satuan & Indeks & Harga satuan (Rp) & Jumlah (Rp) \\
\hline \multirow{3}{*}{ Bahan } & Balok Kayu & $\mathrm{m}^{3}$ & 1,100 & 5.800 .000 & 6.380 .000 \\
\cline { 2 - 6 } & Besi Strip Tebal 5mm & $\mathrm{kg}$ & 15,000 & 8.800 & 132.000 \\
\cline { 2 - 6 } & Paku 12cm & $\mathrm{kg}$ & 3,000 & 9.250 & 27.750 \\
\hline \multirow{3}{*}{ Tenaga Kerja } & Pekerja & $\mathrm{OH}$ & 2,400 & 30.000 & 72.000 \\
\cline { 2 - 6 } & Tukang Kayu & $\mathrm{OH}$ & 7,200 & 37.500 & 270.000 \\
\cline { 2 - 6 } & Kepala Tukang & $\mathrm{OH}$ & 0,720 & 37.500 & 27.000 \\
\cline { 2 - 6 } & Mandor & $\mathrm{OH}$ & 0,120 & 36.000 & 4.320 \\
\hline \multicolumn{3}{|l|}{ Jumlah harga per satuan pekerjaan } & & 6.913 .070 \\
\hline
\end{tabular}

Tabel 11 Memasang $1 \mathrm{~m}^{2}$ rangka atap genteng tanah liat

\begin{tabular}{|l|l|c|l|l|l|}
\hline \multicolumn{2}{|l|}{ Kebutuhan } & Satuan & Indeks & Harga sat.(Rp) & Jumlah (Rp) \\
\hline \multirow{3}{*}{ Bahan } & Balok Kayu & $\mathrm{m}^{3}$ & 0,014 & 3.480 & 48,72 \\
\cline { 2 - 6 } & Reng(2x3)Cm & $\mathrm{m}^{3}$ & 0,036 & 3.480 & 125,28 \\
\cline { 2 - 5 } & Paku 5cm dan 10 Cm & $\mathrm{kg}$ & 0,250 & 8.250 & 2.062 \\
\hline \multirow{5}{*}{ Tenaga Kerja } & Pekerja & $\mathrm{OH}$ & 0,100 & 30.000 & 3.000 \\
\cline { 2 - 5 } & Tukang Kayu & $\mathrm{OH}$ & 0,100 & 37.500 & 3.750 \\
\cline { 2 - 5 } & Kepala Tukang & $\mathrm{OH}$ & 0,010 & 37.500 & 375 \\
\cline { 2 - 5 } & Mandor & $\mathrm{OH}$ & 0,005 & 36.000 & 180 \\
\hline \multicolumn{4}{|l|}{ Jumlah harga per satuan pekerjaan } & & 9.541 \\
\hline
\end{tabular}

Tabel 12 Memasang $1 \mathrm{~m}^{2}$ rangka atap genteng beton

\begin{tabular}{|c|c|c|c|c|c|}
\hline & Kebutuhan & Satuan & Indeks & Harga sat. (Rp) & $\begin{array}{l}\text { Jumlah } \\
\text { (Rp) }\end{array}$ \\
\hline \multirow[t]{3}{*}{ Bahan } & Balok Kayu & $\mathrm{m}^{3}$ & 0,014 & 3.480 & 48,72 \\
\hline & Reng(2x3)Cm & $\mathrm{m}^{3}$ & 0,057 & 3.480 & 198,36 \\
\hline & Paku $5 \mathrm{~cm}$ dan $10 \mathrm{Cm}$ & $\mathrm{kg}$ & 0,250 & 8.250 & 2.062 \\
\hline \multirow[t]{4}{*}{ Tenaga Kerja } & Pekerja & $\mathrm{OH}$ & 0,100 & 30.000 & 3.000 \\
\hline & Tukang Kayu & $\mathrm{OH}$ & 0,100 & 37.500 & 3.750 \\
\hline & Kepala Tukang & $\mathrm{OH}$ & 0,010 & 37.500 & 375 \\
\hline & Mandor & $\mathrm{OH}$ & 0,005 & 36.000 & 180 \\
\hline \multicolumn{5}{|c|}{ Jumlah harga per satuan pekerjaan } & 9.614 \\
\hline
\end{tabular}

Berdasarkan data-data hasil dari perencanaan didapatkan volume pekerjaan dan dengan cara mengalikan dengan harga satuan pekerjaan maka didapat harga pekerjaan.

*) Pekerjaan Kuda-kuda dengan jumlah seluruh kuda-kuda adalah 19 buah, Untuk satu kuda-kuda volumenya adalah $0,315 \mathrm{~m}^{3}$, sehingga untuk 19 buah kuda-kuda volumenya $5,975 \mathrm{~m}^{3}$. Untuk keperluan sambungan volume ditambah $10 \%$ menjadi $6,572 \mathrm{~m}^{3}$. Memasang $1 \mathrm{~m}^{3}$ kuda-kuda konvensional untuk kayu kelas kuat I dengan harga per satuan pekerjaan Rp 7.186.000,00 maka harga pekerjaan kudakuda adalah $\mathrm{Rp} 47.225 .887,00$

*) Pekerjaan Memasang $1 \mathrm{~m}^{3}$ konstruksi gording harga per satuan pekerjaan adalah $\mathrm{Rp}$ 6.913.070,00. Volume pekerjaan untuk gedung $8,755 \mathrm{~m}^{3}$ Untuk keperluan sambungan volume ditambah $10 \%$ menjadi $9,631 \mathrm{~m}^{3}$. Maka harga pekerjaan gording $\mathrm{Rp}$ $66.577 .841,00$

*) Pekerjaan Memasang $1 \mathrm{~m}^{2}$ rangka atap genteng tanah liat Jumlah harga per satuan pekerjaan adalah Rp 9.541,00. volume pekerjaan untuk gedung $879,12 \mathrm{~m}^{2}$. Maka harga pekerjaan rangka atap genteng tanah liat $\mathrm{Rp} 8.387 .684,00$. Pekerjaan penutup atap gentang tanah liat Rp 26.519.534,00. Jumlah anggaran biaya pekerjaan atap dengan kuda-kuda kayu untuk penutup atap dari genteng tanah liat adalah Rp 122.191.412,69

21 Komparasi Biaya Penggunaan Kayu dan Baja Ringan Untuk Konstruksi Kuda-Kuda (Hery Kristiyanto, Agung Yuntoro) 
*) Pekerjaan Memasang $1 \mathrm{~m}^{2}$ rangka atap genteng beton. Jumlah harga per satuan pekerjaan adalah $\operatorname{Rp} 9.614,00$. volume pekerjaan untuk gedung $879,12 \mathrm{~m}^{2}$. Maka harga pekerjaan rangka atap genteng beton $\mathrm{Rp} 8.451 .860,00$. Harga penutup atap gentang beton Rp 24.175.800,00. Jumlah anggaran biaya pekerjaan penutup atap genteng beton $\mathrm{Rp} 32.627 .659,68$. Jumlah anggaran biaya pekerjaan atap dengan kuda-kuda kayu untuk penutup atap dari genteng beton adalah $\operatorname{Rp} 122.255 .588,45$ Perbandingan pekerjaan atap dengan menggunakan kuda-kuda baja ringan dengan kayu, diperoleh selisih harga dalam tabel berikut :

Perbedaan biaya dapat dilihat dalam grafik

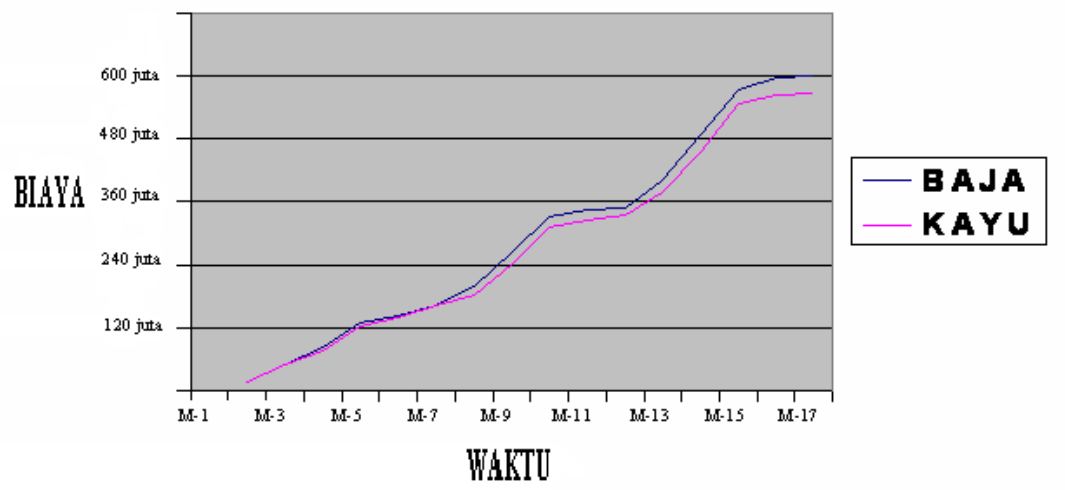

Gambar 3 Grafik perbedaan biaya penggunaan kuda-kuda kayu dengan baja

\section{KESIMPULAN}

1. Anggaran biaya untuk pekerjaan atap dengan kuda-kuda dari kayu bengkirai mutu kayu A adalah Rp 113.803.728,77. Sedangkan anggaran biaya untuk pekerjaan kudakuda baja ringan yang terpasang Rp 114.285.600,00.

2. Selisih biaya antara penggunaan kuda-kuda kayu dengan kuda-kuda baja ringan adalah Rp 481.871,23. Prosentase selisih biaya terhadap nilai pekerjaan adalah 0,42 $\%$. Perbedaan ini menjadi lebih besar ketika penggunaan penutup atap diperhitungkan karena struktur baja ringan menuntut material penutup atap yang ringan dengan harga yang lebih mahal.

3. Biaya setelah penutup atap diperitungkan untuk rangka atap dengan kuda-kuda baja ringan dengan penutup atap dari metal roof biaya mencapai Rp 186.373.440,00. Sedangkan rangka atap dengan kuda-kuda kayu untuk penggunaan genteng tanah liat mencapai biaya $\operatorname{Rp} 140.323 .262,69$ (prosentase selisih biaya $=24,7 \%$ ) dan untuk penggunaan genteng beton mencapai biaya Rp 146.431.388,45 (prosentase selisih biaya $=21,4 \%)$ 


\section{DAFTAR PUSTAKA}

Anonim, 1994, Analisis Struktur II, KMTS Fakultas Teknik UGM

Kardiyono ,1991, Bahan Konstruksi Teknik, KMTS JTS UGM, Yogyakarta.

Padosbajayo, 1994, Pengetahuan Dasar Struktur Baja, Padosbajayo, Yogyakarta.

Peraturan Gubernur Daerah Istimewa Yogyakarta, No : 17 Tahun 2007, Tentang Standarisasi Harga Barang Dan Jasa (SHBJ)

Peraturan Pembebanan Indonesia Untuk Gedung, 1987

Puspantoro, Benny. 1984. Konstruksi Bangunan Gedung, UAJY, Yogyakarta.

RSNI3-3434. 2007, Tata Cara Perhitungan Harga Satuan Pekerjaan Kayu Untuk Konstruksi Bangunan Gedung Dan Perumahan.

SK SNI 03-2445.1991, Spesifikasi Ukuran Kayu Untuk Banggunan Rumah Dan Gedung.

Sunggono, 1995, Buku Teknik Sipil, Nova, Bandung.

Tjokrodihardjo, S., 1994, Analisis Struktur IV, KMTS Fakultas Teknik UGM.

23 Komparasi Biaya Penggunaan Kayu dan Baja Ringan Untuk Konstruksi Kuda-Kuda (Hery Kristiyanto, Agung Yuntoro) 